\title{
Exosome: emerging biomarker in breast cancer
}

Review

\author{
Yunlu Jia ${ }^{1,2}$, Yongxia Chen ${ }^{1,2}$, Qinchuan Wang ${ }^{1,2}$, Ushani Jayasinghe ${ }^{3}$, Xiao Luo ${ }^{4}$, \\ Qun Wei ${ }^{1,2}$, Ji Wang ${ }^{1,2}$, Hanchu Xiong ${ }^{1,2}$, Cong Chen ${ }^{1,2}$, Bin $\mathrm{Xu}^{1,2}$, Wenxian $\mathrm{Hu}^{1,2}$, \\ Linbo Wang ${ }^{1,2}$, Wenhe Zhao ${ }^{1,2}$ and Jichun Zhou ${ }^{1,2}$ \\ ${ }^{1}$ Department of Surgical Oncology, Sir Run Run Shaw Hospital, Zhejiang University, Hangzhou, Zhejiang, China \\ 2 Biomedical Research Center and Key Laboratory of Biotherapy of Zhejiang Province, Hangzhou, Zhejiang, China \\ ${ }^{3}$ Brown University, Providence, Rhode Island, USA \\ ${ }^{4}$ Department of Radiology, Second Affiliated Hospital, Zhejiang University, Hangzhou, Zhejiang, China \\ Correspondence to: Linbo Wang, email: linbo.wang@aliyun.com
}

Wenhe Zhao, email: onco-surg@163.com

Jichun Zhou, email: zjc0305@live.cn

Keywords: breast cancer, exosome, metastasis, drug resistance, cancer therapy

Received: January 10, $2017 \quad$ Accepted: March 10, $2017 \quad$ Published: March 29, 2017

Copyright: Jia et al. This is an open-access article distributed under the terms of the Creative Commons Attribution License 3.0 (CC BY 3.0), which permits unrestricted use, distribution, and reproduction in any medium, provided the original author and source are credited.

\section{ABSTRACT}

Exosomes are nano-sized membrane vesicles released by a variety of cell types, and are thought to play important roles in intercellular communications. In breast cancer, through horizontal transfer of various bioactive molecules, such as proteins and mRNAs, exosomes are emerging as local and systemic cell-to-cell mediators of oncogenic information and play an important role on cancer progression. This review outlines the current knowledge and concepts concerning the exosomes involvement in breast cancer pathogenesis (including tumor initiation, invasion and metastasis, angiogenesis, immune system modulation and tumor microenvironment) and cancer therapy resistance. Moreover, the potential use of exosomes as promising diagnostic and therapeutic biomarkers in breast cancer are also discussed.

\section{INTRODUCTION}

Breast cancer is one of the most common malignancies in women [1]. According to report of the American Cancer Society, breast cancer alone take over $29 \%$ all new cancer diagnoses in women in 2016, and it is expected to be leading cause of cancer-related death in women aged from 20 to 59 years [2]. Past decades have witnessed various cutting-edge diagnostic and prognostic methods and the improvement of novel targeted therapies due to major advances in our deeper comprehension of breast cancer biology. Currently, available treatments efficacy of breast cancer is still limited by drug toxicity and resistance and lack of dependable predictive and prognostic biomarkers. Thus, accelerating progress against breast cancer requires both the development of novel biomarkers and therapeutic targets and further understanding of the potential molecular mechanisms.

Exosomes are 40-100nm diameter membrane vesicles of endocytic origin, which are secreted by various kinds of cells and contain a broad repertoire of cargoes, including nucleic acids (ex., DNA, mRNA, miRNA, long and short noncoding RNA), proteins (ex., cytoskeletal proteins, Transmembrane proteins, and heat shock proteins), and enzymes (GAPDH, ATPase, pgk1) [3]. Generally, contents of exosomes can reflect the nature and status of original cells. The upgrading of specific proteins and nucleic acids implies a degree of specific cellular sorting into exosomes [4]. On the other end of spectrum, exosomes have the ability of modulating cellular activities in recipient cells by transferring genetic information $[5$, $6,7]$.

Recently, research on the role of exosomes involved tumorigenesis and cancer progression has grown exponentially, including immune suppression, angiogenesis, cell migration and invasion [6-8]. As exosomes are capable of transferring specific proteins and nucleic acids to recipient cells in the tumor microenvironment or at specific distant sites, cancers have used exosomes as a tool by which cancer cells can transfer malignant phenotype to normal cells, and 
establish a fertile local and distant microenvironment to help cancer cell growth [9]. Contents as miRNA and proteins found in tumor-derived exosomes isolated from patients' bodily fluids play an important role in cancer development and progression [10] [11]. These features render exosomes as potential biomarkers for liquid biopsy, and utilizing exosomal profiling in the absence of tissue hold pronounced promise for disease early diagnose and therapy efficacy monitoring.

Increasingly, exosomes are studied for their potential roles as both indicators of breast cancer and a prospective new treatment approach. Exosomes can play important roles in different stages of development in breast cancer. Through horizontal transfer of genetic information between breast cancer cells, exosomes are supposed to exhibit pleiotropic biological functions, including stimulating tumor angiogenesis, reorganizing the stroma to establish the tumor microenvironment, as well as promoting tumor growth and drug resistance. This comprehensive review highlights our understanding of the contribution of the exosomes during breast cancer development and evolution. We will also discuss key concepts on their possible clinical applications, including their use as prognosis biomarkers and novel therapeutic targets, such as drug delivery system and exosome-based vaccine.

\section{BIOGENESIS AND CHARACTERISTICS OF EXOSOMES}

Exosomes are membrane vesicles of endocytic origin, which shaped from inward budding of membrane of multi-vesicular bodies (MVB) and released from the cell into the extracellular environment with the plasma membrane. Most prokaryotic and eukaryotic cells can release exosomes, including stroma cell, reticulocytes, epithelial cells, and tumor cells, which have been isolated from serum, urine, bile, and breast milk [3-5] [7] [12]. According to proteomic analyses, exosomes have been verified to contain a selective enrichment of a discrete set of cellular protein associated with cell surface receptors, cytosolic signaling proteins, metabolic enzymes, antigen presentation, and major histocompatibility complex

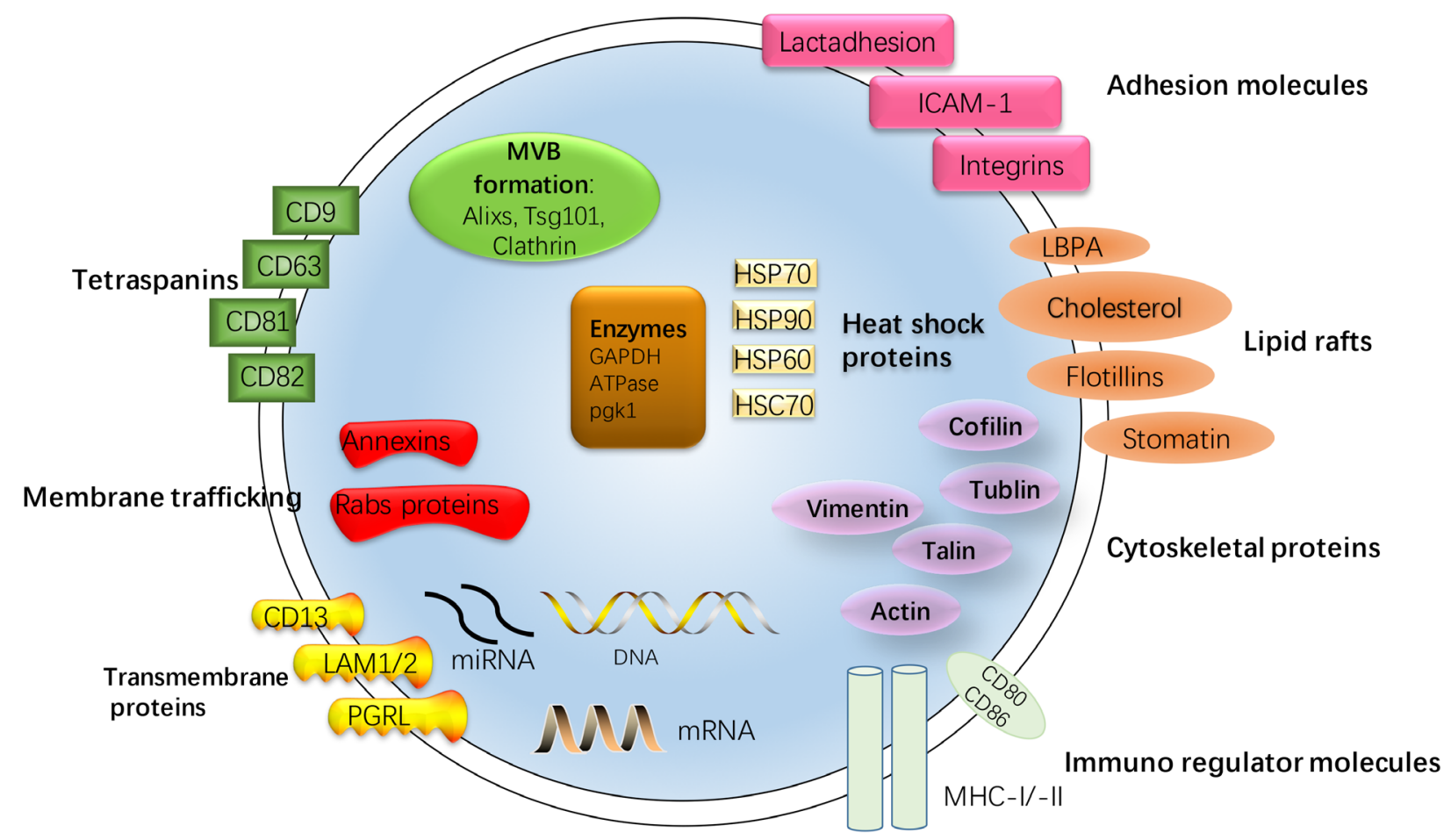

Figure 1: Structure and contents of exosomes. Exosomes are small membrane bound vesicles sharing similar topology to the plasma membrane. The lipid bilayer membrane structures of exosomes carry contains typical transmembrane proteins and receptors, such as the transmembrane proteins PGRL, LAMP1/2, CD13, membrane trafficking proteins as annexins and RABs proteins, adhesion molecules as ICAM-1, Lactadhesion and intergrin, the lipid raft associated protein as Flotillins, LBPA, Cholesterol, stomatin and tetraspanins, most characteristically CD63 and CD81. Furthermore, the exosomal membranes surface is assembled with Immuno regulator molecules, such as MHC-I and -II, CD80 and CD86. Within the exosomal lumen several proteins stabilizing and conserving the 'informative' exosomal cargo can be found: Cytoskeleton proteins, HSPs, most typically Hsp70, cytoskeletal proteins (Vimentin, Cofilin, Tublin, Talin, Actin), metabolic enzymes (GAPDH, ATPase, pgk1) and protein involving in MVB formation as Alixs, Tsg101, Clathrin. The contents of exosomes can be transferred from the original cell to their target cells in microenvironment, consisting of RNA species (mRNAs, miRNAs and other types of short RNAs), and a vast array of different proteins depending on their host cell. 
Table 1: Difference between exosomes and MVs

\begin{tabular}{|l|l|l|}
\hline Size and Shape & \multicolumn{1}{|c|}{ Exosomes } & \multicolumn{1}{|c|}{ MVs } \\
\hline Formation & $\begin{array}{l}30-100 \mathrm{~nm} ; \\
\text { a characteristic round or cup-shape }\end{array}$ & $\begin{array}{l}100 \mathrm{~nm}-1000 \mathrm{~nm} \text {; composed of } \\
\text { a round-shaped, heterogeneous } \\
\text { population }\end{array}$ \\
\hline Components & $\begin{array}{l}\text { Budding to the inside of late } \\
\text { endosomes }\end{array}$ & $\begin{array}{l}\text { budding towards the outside from } \\
\text { the plasma membrane }\end{array}$ \\
\hline & $\begin{array}{l}\text { Heat shock proteins (HSP70, } \\
\text { HSP90, HSP60, HSC70) } \\
\text { Tetraspanins (CD9, CD63, CD81, } \\
\text { CD82) } \\
\text { Membrane trafficking (Annexins, } \\
\text { Rabs proteins) } \\
\text { Adhesion molecules, Cytoskeletal } \\
\text { proteins, regulator molecules, } \\
\text { Immuno reghatidylserine, } \\
\text { Enzymes, miRNA, mRNA and } \\
\text { DNA }\end{array}$ & $\begin{array}{l}\text { Integrins, } \\
\text { Selectins, } \\
\text { CD40 ligand }\end{array}$ \\
\hline
\end{tabular}

(MHC), heat shock protein (HPSs, as HSP70, HSP90, HSP60, HSP70), and tetraspanins [13, 14]. Although previously considered as cellular waste products, recent studies have showed that exosomes carry amount of functional molecules, provide shelter to the transported molecules and act as intercellular correspondents by shuttling molecules between cells [12] [15] [16]. Here, the structure and contents of exosomes is demonstrated in Figure 1.

There are a large number of mobile membranelimited vesicles called extracellular vesicles (EVs) in the extracellular environment, which can be further

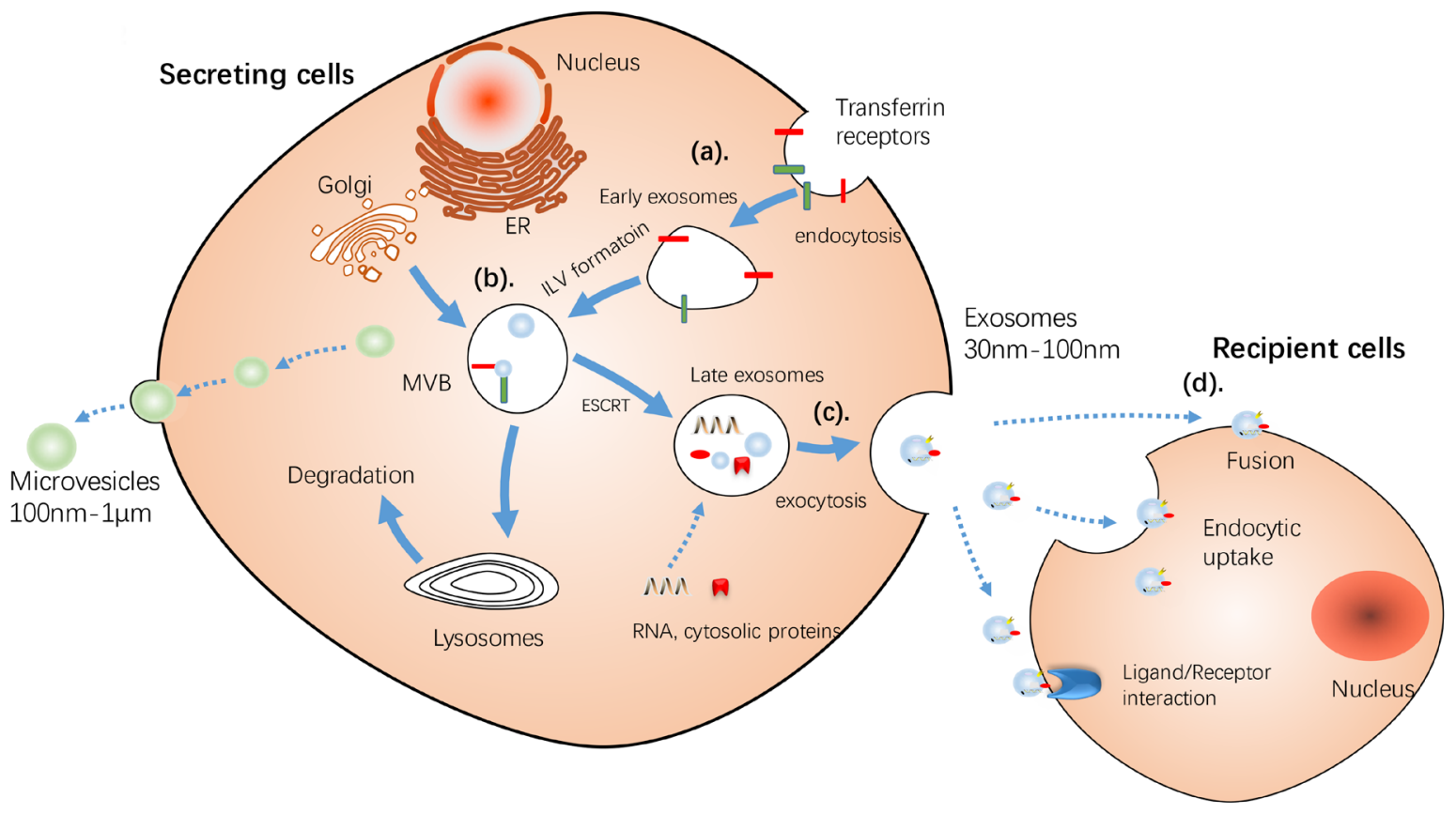

Figure 2: Schematic illustration of Release of MVs and exosomes. MVs bud directly from the plasma membrane, whereas exosomes are repressed by small vesicles of different sizes that are formed as the ILV by budding into early endosomes and multivesicular body and are released by fusion of multivesicular body fuse with lysosomes. a. By endocytosis of membrane segments, the initial endosome arises, containing receptors and transmembrane proteins of the plasma membrane. b. Instead of lysosomal degradation, the matured late endosome transforms by inward budding of tiny vesicles into a multivesicular body. Furthermore, the exosomal cargo as proteins and miRNA, is selectively loaded into the vesicles. c. MVs bud directly from the plasma membrane, whereas the exosomes are released into the extracellular space by fusion of the multivesicular body with the plasma membrane d. Cell-secreted exosomes can travel through biological fluids (e.g. serum, lymph) and be internalized by recipient cells. Three different sorting complexes have been identified so far: the ESCRT pathway with its associated proteins ALIX and TSG101, the ceramide-dependent sorting complex and a tetraspanin-mediated sorting pathway including CD63, CD81 and TSPAN8. ESCRT: endosomal sorting complex required for transport machinery. MT, mitochondria; MVB, multivesicular bodies. 
Table 2: Major miRNAs involved in breast tumor progress

\begin{tabular}{|c|c|c|}
\hline miRNA/Protein & target genes & physiological function \\
\hline miR-130a & TGB- $\beta /$ Smad signaling & tumorigenesis \\
\hline $\operatorname{miR}-328$ & CD44 & reduce cell adhesion and enhance cell migration \\
\hline miR-301a & & a negative prognostic maker \\
\hline $\operatorname{miR}-34 \mathrm{a}$ & p53 & \\
\hline miR-106b & BRMS1; RB & an early process of tumor metastasis \\
\hline $\operatorname{miR}-10 b$ & HOXD10; KLF4 & $\begin{array}{l}\text { transfer to non-maligant HMLE cells and promote cell } \\
\text { invasion }\end{array}$ \\
\hline miR-105 & ZO-1 & cell migration and metastasis \\
\hline $\begin{array}{l}\operatorname{miR}-127,-197,-222 \text {, and } \\
-223\end{array}$ & CXCL12 & $\begin{array}{l}\text { suppress cell proliferation and elicit cell cycle } \\
\text { quiescence }\end{array}$ \\
\hline miR-23b & & promote cell dormancy in a metastatic niche \\
\hline $\operatorname{miR}-373$ & & $\begin{array}{l}\text { downregulate ER expression and inhibition of } \\
\text { apoptosis }\end{array}$ \\
\hline miR-122 & & $\begin{array}{l}\text { inhibit glucose uptake in a premetastatic niche and } \\
\text { promote metastasis }\end{array}$ \\
\hline $\operatorname{miR}-9$ & & $\begin{array}{l}\text { transfer cancer-associated fibroblasts phenotype to } \\
\text { normal fibroblasts }\end{array}$ \\
\hline $\operatorname{miR}-223$ & Mef $2 \mathrm{c}-\beta$-catenin pathway & promote invasiveness of breast cancer \\
\hline miR-16 & VEGF & suppress angiogenesis \\
\hline $\operatorname{miR}-210$ & & $\begin{array}{l}\text { key factors for the tumor angiogenesis and brain } \\
\text { metastasis }\end{array}$ \\
\hline $\begin{array}{l}\text { miR-451, miR-326, miR- } \\
\text { 100, miR-222, and miR- } \\
30 \mathrm{a}\end{array}$ & & drug resistance \\
\hline $\operatorname{miR}-221 / 222$ & & enhance tamoxifen resistance \\
\hline $\begin{array}{l}\text { miR-155, miR-21 and } \\
\text { miR-1246, }\end{array}$ & the shelterin component TERF1 & cancer diagnose and predict a poor prognosis \\
\hline $\begin{array}{l}\text { miR-215, miR-299, and } \\
\text { miR-411 }\end{array}$ & & $\begin{array}{l}\text { lower expression in untreated patients with metastatic } \\
\text { breast cancer }\end{array}$ \\
\hline $\begin{array}{l}\operatorname{miR}-155 \text {, miR-19a, miR- } \\
181 b \text {, and miR-24 }\end{array}$ & & an early marker for breast cancer risk \\
\hline $\begin{array}{l}\operatorname{miR}-101, \text { miR-939, miR- } \\
373\end{array}$ & & breast tumor subtype and stage \\
\hline
\end{tabular}

subcategorized based on their size, biogenesis and release mechanism, and content into exosomes, microvesicles (MVs), and apoptotic bodies [3] [17]. Exosomes and MVs have a distinct biogenesis, while the most dramatic difference between exosomes and MVs is how they are formed [18]. Exosomes are formed from inward budding of an endosome resulting in a multivesicular body (MVB), with the plasma membrane, which is secreted by succeeding fusion of the MVB. On the other hand, MVs are released directly by budding from the cellular plasma membrane (detailed difference between exosome and MVs are summarized in Table 1) [19-22]. Moreover, most of discussed studies claimed that their studies were based on exosomes. Henceforth, exosomes and microvesicles are collectively referred to as exosomes unless indicated. (The release process of MVs and exosomes is showed Figure 2)

Several studies has indicated the potential mechanisms by which exosomes are internalized and released. Accumulating evidence has indicated that impose stress on cells, growth factors and increases in intracellular calcium can induce the release of exosomes $[23,24]$. Exosomes also exert a feedback mechanism regulating the release of exosomes from normal mammary, it means that exosomes released from breast 
cancer cells and normal human mammary epithelial cells are regulated by exosomes derived from their own cells [25]. Other investigations have revealed that that exosomes are internalized via phagocytosis or lipid raft domains [26] [27]. In breast tumor cells, detachment of cells is a intense stimulation for the secretion of exosomes [28]. Exosomes have also been expected to contributed to cell-cell communication by activating them directly by surface expressed ligands or by conveying signal molecules between cells. To be specific, exosomes interact with target cells via receptors, endocytosis, fusion with plasma membrane, or the release of their cargo [29, 30]. Cancer cell derived exosomes usually carry molecular signs and effectors of the disease, such as mutant oncoproteins, oncogenic transcripts, microRNA, and DNA sequences. When taken up by recipient non-malignant cells, such exosomes contribute to horizontal cellular transformation and phenotypic reprograming, traverse the tumor microenvironment, and finally result in the cell malignant transformation [14, 31]. What is more, as the content of exosomes is closely connected to the original cells which the exosomes are derived, exosomes are increasingly considered as novel diagnostic or prognostic biomarkers [32]. Recently, growing number of studies have also revealed the important role of exosomes as both indicators of cancer development and a prospective new treatment approach in breast cancer.

\section{TUMOR TRANSFORMATION}

During initial malignant transformation, exosomes generated by breast cancer cells contain a variety of proteins and RNA species can be transfected between cancer cells as well as cancer and normal cells, conferring a transformed-like phenotype to normal mammary epithelial cells. Although the exact underlying mechanisms remain to be elucidated, many research findings have revealed that exosomes could alter the transcriptomes of target cells and contribute to oncogenic transformation and tumor formation [33] [34]. For example, exosomes secreted by breast caner cell (MDA-MB-231) were capable of transforming normal human mammary epithelial cells (MCF10A cells) into cancer cells [35]. In cell culture and mice models, these cancer exosomes contained miRNAs (miR-10b and miR-21) altered the transcriptome of recipient cells, with the RNA-induced silencing complex (RISC)-loading complex proteins (RLC), and process premiRNAs Dicer, TAR RNA-binding protein 2 (TRBP) and

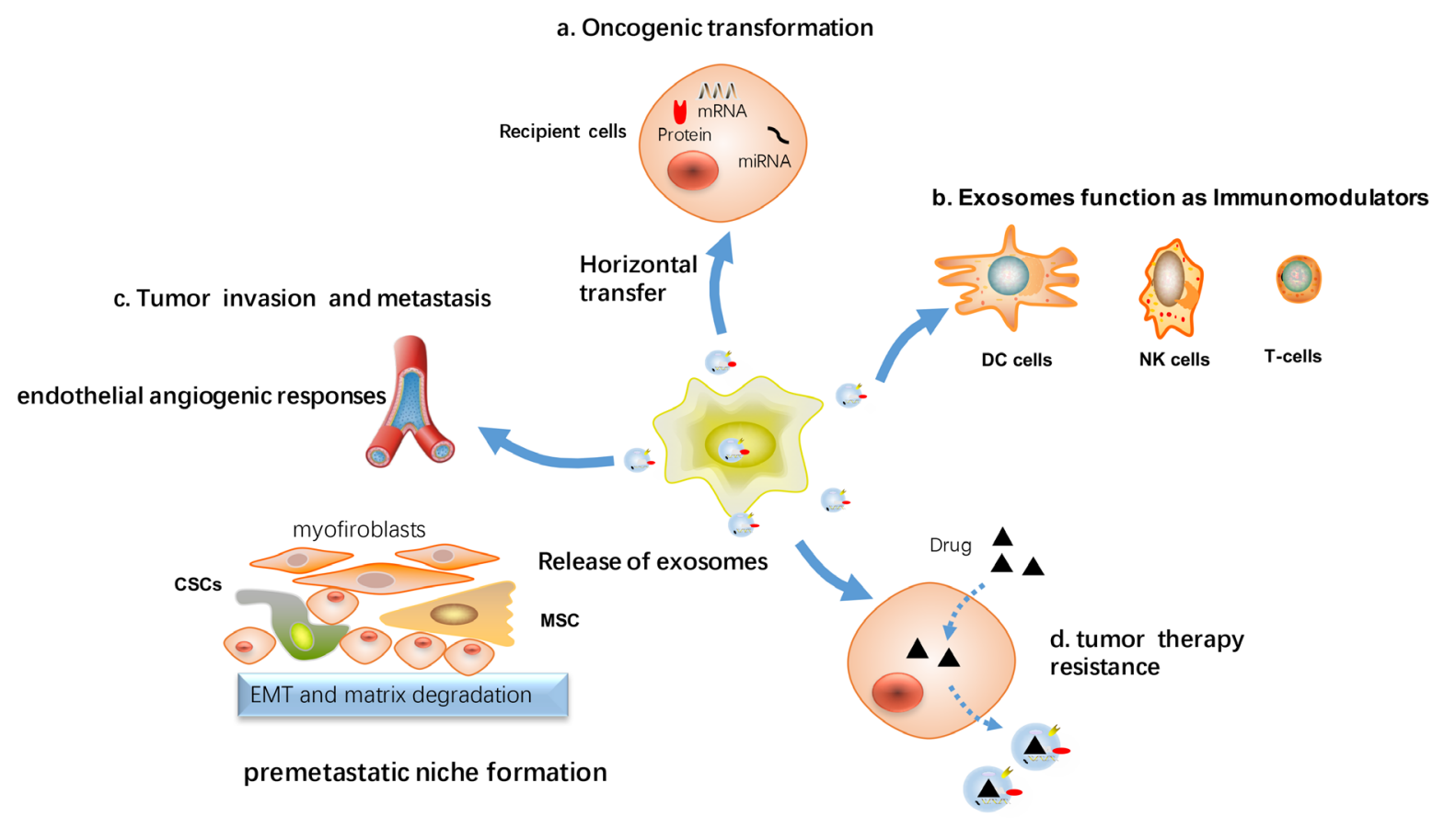

Figure 3: Cellular processes affected by exosomes-mediated signaling in breast cancer. Tumor cells and stromal cells exchange exosomes carrying proteins and nucleic acids that can affect the function of recipient cells. a. Via horizontal transfer of protein or RNA, exosomes can contribute to the spread of the transformed phenotype from tumor cells to surrounding normal cells. b. Inhibition of the immune response against tumor cells by inhibiting the proliferative response of immune cells (DC cells, NK cells and T-cells). c. Exosomes influence tumor invasion and metastasis, as stimulate endothelial angiogenic responses, epithelial to mesenchymal transition (EMT), activate cancer stem cell and preparation of a premetastatic niche at the distant location. d. Induction of cancer therapy resistance including chemoresistance, radiation resistance, endocrine and target therapy resistance. 
Argonaute-2 (AGO2) into mature miRNAs. In addition to exosomes acting locally to promote tumor formation and proliferation, they can also impact cells at distant sites through their ability to affect cell migration and invasion capacity.

\section{HALLMARKS OF TUMOR GROWTH, INVASION AND MIGRATION}

In breast cancer, in addition to taking part in initial malignant transformation, exosomes can transfer signaling molecules to cancer cells within the tumor microenvironment, and help tumor cells evade immune response, promote tumor invasion and metastasis, remodel the tumor microenvironment, and stimulate angiogenesis (Figure 3).

Metastasis requires cell manipulate local environment to optimize invasion and growth, including loss of adhesion, increased migration and invasion [36-
38]. Adhesion is extremely important not only in various pathological conditions but also in cancer biology. In breast cancer cells, cellular detachment is related with significant release of exosomes, and then exosomes concentrate on the cell surfaces and mediate adhesion to extracellular matrix proteins [28] [39]. Fetuin-A, a glycoprotein from fetal bovine serum, has been proved to provide a significant clue regarding cellular adhesion [40]. Via recruiting exosomes, Fetuin-A can mediate cancer cells adhesion [41], and these exosomes also contribute to the preparation of the metastatic niches and regulate cell growth and motility [42] [43]. Taken together, these currently available data show that exosomes isolated from breast cancer cells can stimulate cell migration and induce migration proportional to the metastatic potential of the cell [44].

Plenty of research have shown that miRNAs secreted from exosomes improve the invasive and migration capacity of several breast cancer cell lines. Kruger et

\section{e. angiogensis and tumor invasion}

\section{a. Malignant transformation}

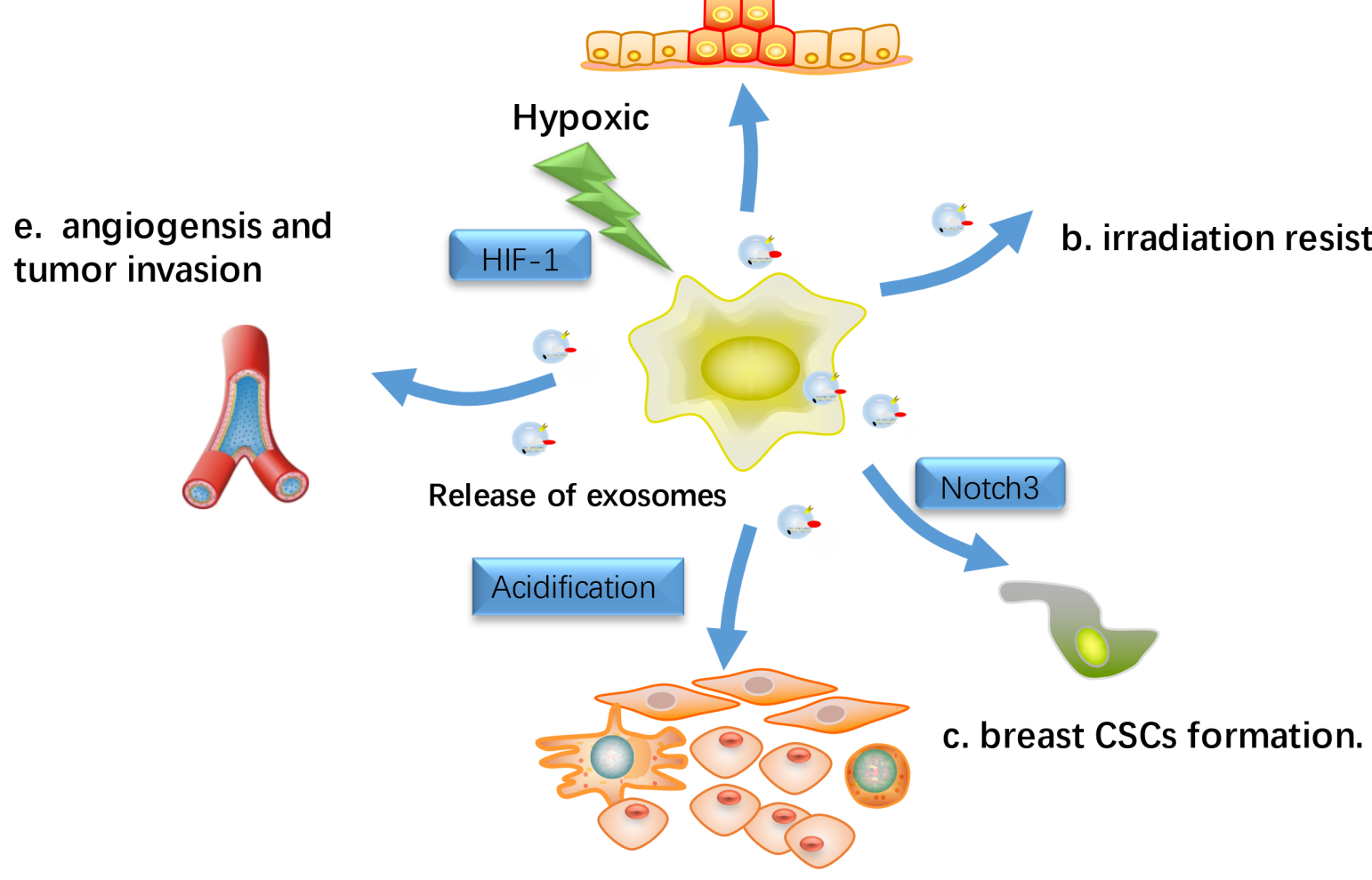

\section{d. Tumor microenvironment}

Figure 4: Hypoxic effects on exosomes-Influenced metastasis. Hypoxia has been regard as a major trigger for the release of exosomes release in breast cancer cell, and the hypoxia-induced release of exosomes from cancer cells is hypothesized to result in the malignant transformation and subsequent proliferation and migration of normal recipient cells. a. Transfer miRNA or protein to recipient cells and lead to malignant transformation in normal cells. b. Hypoxic tumor microenvironments render cancer cells more resistant to irradiation. c. Hypoxic induced exosomes induce the stem cell regulatory gene Notch3 in breast CSCs d. Hypoxia resulted in acidification of the tumor microenvironment, which may have a profound influence on exosomes release and uptake. e. facilitate angiogenesis and tumor metastasis. 
al. investigated exosomes derived from MDA-MB-231 encompassed a higher level of matrix metalloproteinase proteins, while the exosomes derived from MCF-7 contained more nucleic acid, transfer proteins, and protein binding. In addition, the Gene Ontology analysis revealed that several of profiled miRNAs are related with tumor progression and metastasis, and a bundle of miRNAs (including miR-301a, miR-130a, miR-34a, miR-106b, miR-328 etc.) had different expression levels between MDA-Exo and MCF-Exo [45]. Exosome-mediated miR$10 \mathrm{~b}$ secretion suppressed the protein level of its target genes such as HOXD 10 and KLF4 and induced invasion ability in breast cancer cell [46]. Characteristically expressed and secreted by metastatic breast cancer cells, miR-105 regulated cell migration through targeting $\mathrm{ZO}-$ 1 [47]. Breast cancer cells secreted miR-122 promoted cell metastasis by adjusting the metabolic environment to a premetastatic niche. By inhibiting glucose uptake by premetastatic niche cells, exosomal miR-122 reprogramed systemic energy metabolism and enhanced cancer development [48]. In addition, tumor-secreted exosomal miR-9, upregulated in various breast cancer cell lines and known as a pro-metastatic miRNA, can be taken up by normal fibroblasts and switch to cancer-associated fibroblasts phenotype, thus contributing to tumor growth [49]. Bone metastasis is a frequent event in breast cancer, and transfer of exosomal miRNAs is functional mediators of tumor-stromal communications in breast cancer bone metastasis. Authors identified four exosomes-secreted miRNAs (miR-127, -197, -222, and -223) that inhibited
CXCL12 expression in co-cultured MDA-MB-231 and T47D to suppress cell proliferation and stimulate cell cycle quiescence [50]. In breast cancer cells, exosomal miR-23b promoted dormancy and decreased CD44 surface abundance, a characteristic marker of breast cancer stem cells (CSCs). Exosomal transfer of miR-23b from the bone marrow and its suppression of MARCKS caused breast cancer cell quiescence in metastatic niches [51].

Triple-negative breast cancers (TNBC) are defined as lack of expression of progesterone receptor (PR) and oestrogen receptor (ER) and amplification of human epidermal growth factor receptor 2 (HER2) gene. TNBC derived exosomes could confer phenotypic traits to secondary cells via cell-to-cell communication. Study has revealed TNBC cell line Hs578Ts(i) ${ }_{8}$-exosomes significantly improved the proliferation, migration and invasion abilities of the recipient cell lines, and stimulated sensitivity to anoikis [52]. The preoperative blood serum levels of miRNA from patients with breast cancer revealed association between the level of exosomal miR-373 to triple negative and more aggressive breast cancer. Exogenous overexpression of miR-373 in MCF7 cells caused downregulated protein expression of RE, and suppression of apoptosis induced by camptothecin [53]. Exosomes derived from noncancerous cells can also influence cancer progression. Wnt signaling pathway can directly stimulate exosomes secretion and participate in the transportation of exosomal molecules in breast cancer progression. Fibroblast-secreted exosomes promoted breast cancer cell invasion and metastasis by stimulate

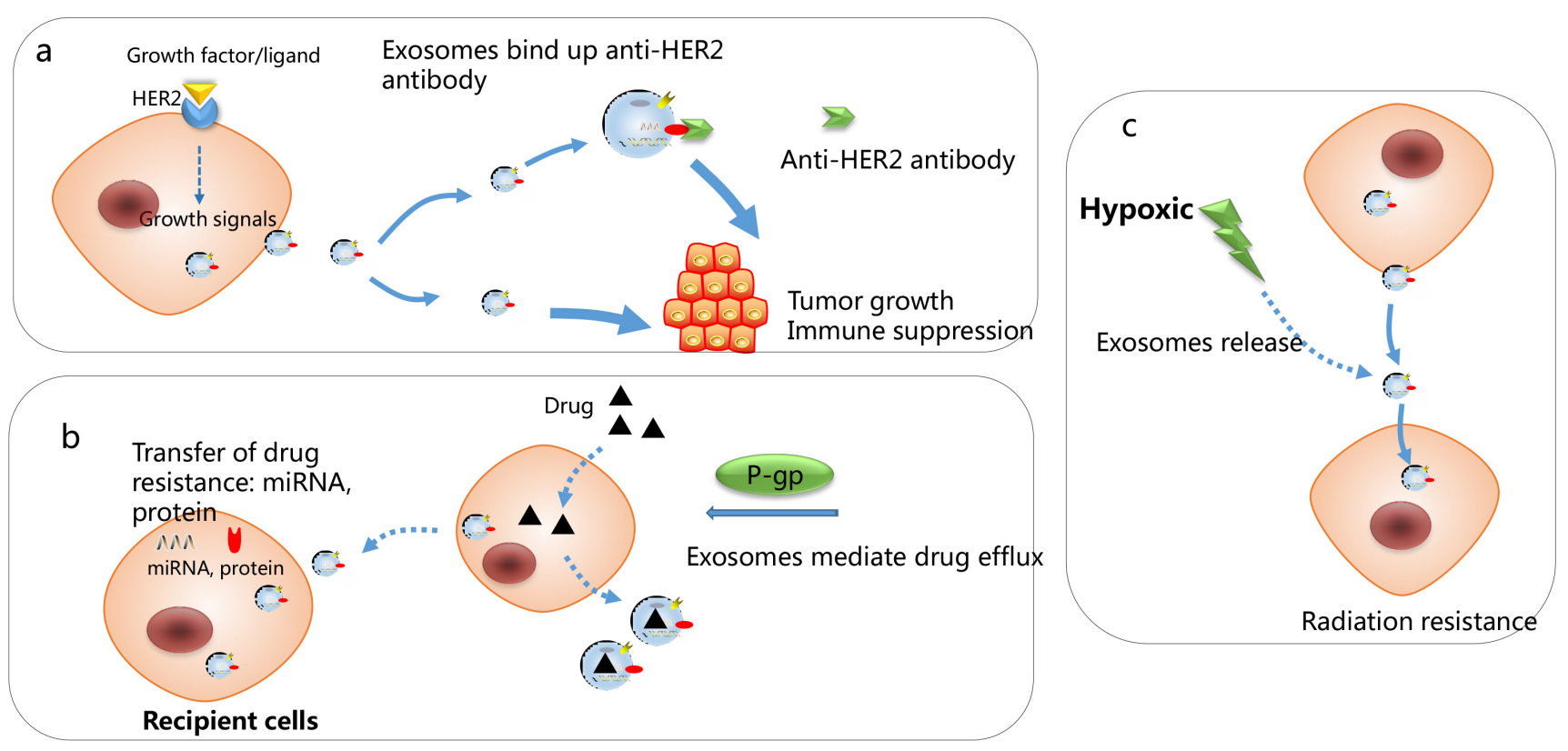

Figure 5: Mechanisms responsible for exosomes-associated drug resistance. a. HER2 positive derived exosomes" could bind efficiently to Trastuzumab and inhibit the anti-proliferative effects of trastuzumab by preventing it from binding to tumor cells. b. Exosomes mediate drug efflux and transfer of drug resistance to recipient cells, through transfer of miRNAs and protein. c. Hypoxic-induced exosomes render cancer cells more resistant to irradiation. 
epithelial-mesenchymal transition (EMT) and matrix degradation via Wnt-planar cell polarity signaling [54]. Macrophages promoted invasiveness of breast cancer cells via deliver invasion-potentiating miR-223, via regulation of the Mef2c- $\beta$-catenin pathway [55]. Major exosomal miRNAs involved in breast tumor progress is exhibited in Table 2, including their target genes and mainly physiological function.

\section{EXOSOMES INFLUENCE ON TUMOR GROWTH UNDER HYPOXIC ENVIRONMENT}

Hypoxic, an often transient phenomenon presents at microscopic sites within tumors microenvironment, which is linked to angiogenesis, tumor aggressiveness, treatment resistance and poor outcomes in a range of different cancers. With a unique ability, cancer cells can survive and grow under hypoxic environments [56]. In breast cancer cells, hypoxia condition is regarded as a major trigger for exosomes secretion [57, 58]. Under hypoxic conditions, the effects of exosomes on tumor angiogenesis and growth are even more noticeable [59-61] (Figure 4). It has been reported that hypoxia-induced release of exosomes from cancer cells may lead to neoplastic transformation, malignant cell growth and invasion [6264]. Hypoxia was also favorable for exosomes trafficking due to tumor microenvironment acidification, as exosomes release and uptake have been indicated to be facilitated at lower $\mathrm{pH}$ [65]. Park et al. revealed that hypoxic or reoxygenated epidermal carcinoma cells secreted exosomes with the potential to regulate cell microenvironment and improve angiogenesis and metastasis [66]. This result was recapitulated in breast cancer. In breast cancer, hypoxiamediated triggering of HIF-1 $\alpha$ (Hypoxia inducible factors) enhanced exosomes secretion and lead to aggressive cell phenotype [67]. Breast cancer-derived exosomes produced under hypoxic conditions can also promote inflammatory crosstalk within the tumor niche to promote growth, which is decreased by activation of nuclear receptors within the cancer cell [68]. Besides, tumor cells made cancer cells significantly reduce the effectiveness of irradiation under hypoxic tumor microenvironments. It has been reported hypoxic regions in breast cancers is more resistant to radiation and chemotherapy [69].

\section{EXOSOMES CONTRIBUTE TO TUMOR PROGRESSION VIA MODULATING STEM CELLS}

Mesenchymal stem cells (MSCs) have the potential for self-renewal and act as precursors for tumor stroma including myofibroblasts, which are key cells of tumor stroma and play an important role in the tumor angiogenesis. [70] [71]. Karnoub et al have suggested an interaction between breast cancer progression and MSCs [72]. Tumor-derived exosomes can contribute to breast cancer development by converting adipose tissue-

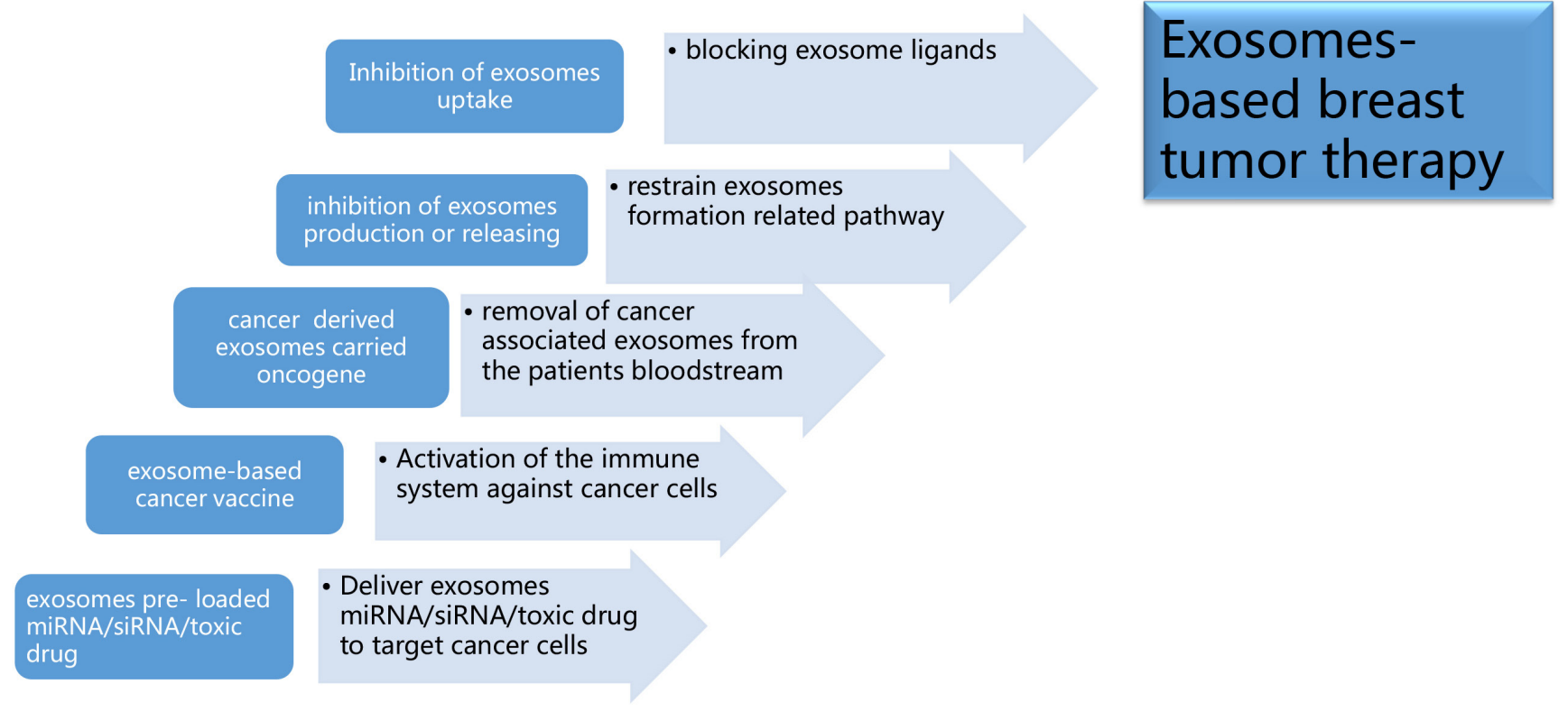

Figure 6: Exosomes-based breast tumor therapy. a. Deliver exosomes containing miRNA, small interference RNA (siRNA), and/ or anti-cancer drugs to target cancer cells; $\mathbf{b}$. Activation of the immune system against cancer cells by implementing vaccines of exosomes containing proteins with unique or higher expression in tumor cell; $\mathbf{c}$. To removal cancer or stromal derived exosomes containing oncogene related components from cancer patients' circulation via molecule sponge or a hemodialysis-like process; d. To decrease oncogenic components containing exosomes production or releasing through targeting exosomes formation related pathway; e. Inhibition of exosomes uptake in recipient cells by blocking exosome ligands. 
MSCs into tumor-associated myofibroblasts, and exosome treatment can increase the expression of tumor-stimulating molecules (SDF-1, VEGF, CCL5 and TGF $\beta$ ) [73]. Ruizhu Lin et al have verified MSC secreted exosomes significantly promoted MCF-7 migration via triggering Wnt signaling pathway [74]. MCF-7-derived exosomes also modulated breast cancer stem cells (CSCs) formation. Notably, MCF-7 derived exosomes significantly induced the stem cell regulatory gene $\mathrm{NOTCH} 3$ in breast CSCs under hypoxic microenvironment [68]. MCF-7-derived exosomes up-regulated the activation marker CD44, the CSCs growth factor IL6, as well as ApoE. In another study, 4T1 mouse breast derived exosomes functioned as pro-tumorigenic factors by promoting the cell growth and suppression apoptosis of CD133 + tumor stem cells [75].

\section{EXOSOMES ACT AS STIMULATING FACTORS FOR TUMOR ANGIOGENESIS}

Exosomes are important mediators in promoting cell angiogenesis. Previously study has suggested that breast cancer cells derived exosomes converted MSMs into myofibroblasts via a SMAD-mediated pathway [76]. Myofibroblasts, which are key cells of tumor stroma and play an important role in the tumor angiogenesis. Thus, Exosomes from breast cancer cells tumor exosomeinduced recruitment of fibroblasts could support tumor angiogenesis. Breast cancer cell-derived exosomal miR16 downregulated VEGF expression in cancer cells and suppressed angiogenesis, which could be consider as an effective anti-angiogenetic agent for anti-tumor therapy [77]. The correlation between circulating miR210 and tumor presence and lymph node metastases in breast cancer patients has been well established. Neutral sphyngomyelinase 2 (nSMase2) affected exosomal miRNA secretion and promoted cancer cell metastasis through the induction of angiogenesis in the tumor microenvironment. Specifically, exosomal angiogenic miRNAs from metastatic breast cancer cells, such as miR-210, promoted their metastatic initiation efficiency via enhancing endothelial cells migration and capillary formation [78]. Exosomal miR-210 might be one of the key factors for tumor angiogenesis and brain metastasis, and high expression of miR-210 predicted poor survival in breast cancer patients with brain metastatic [79, 80].

\section{INTERACTION BETWEEN EXOSOMES AND TUMOR MICROENVIRONMENT IN CANCER PROGRESSION}

Tumor cells can create microenvironments (premetastatic niche) suitable for cancer distance metastasis [81]. Tumor cell-derived exosomes act as a vehicle for the horizontal transfer of exosomal miRNAs and protein between epithelial cells, stromal cells, macrophages, and fibroblasts and tumor cells, manipulating the tumor microenvironments to establish premetastatic niche which is more permissive for cancer invasion and migration [82] [83]. Moreover, authors proposed that tumor-derived exosomes might contribute to metastatic niche form to promote tumor metastasis [84] [85].

The cell factors secreted to the tumor microenvironment from preadipocytes and adipocytes are important components of the cancer stem cell niche and exert their oncogenic effects in vivo [86]. Cancer-derived extracellular miR-122 convert the metabolic environment to a premetastatic niche, by suppressing cells glucose uptake and reprograming systemic energy metabolism [48].

More recently, by injecting mice with exosomes taken from breast-cancer cells, exosomes have been proved to be involved breast cancer organ-specific metastasis. The underlying mechanism may be that exosomes expressed different cell-adhesion receptor proteins (called integrin) on their surface can target different organs and the specific organs recruited an abundance of ligand for the receptor. For instance, exosomal $\alpha v \beta 5$ integrin directed to the liver, whereas $\alpha 6 \beta 4$ promoted homing to the lung [87] [88]. Thus, exosomal integrin profiles might predict organspecific metastasis and act as a new biomarker in cancer diagnostics, and integrin inhibitors might curtail metastatic spread to specific organs.

\section{DUAL-EFFECT OF EXOSOMES IN TUMOR IMMUNE SYSTEM REGULATORY}

Cancer cells escape the host immune system through manipulating their own immunogenicity and activation of immunosuppressive mediators [89]. Exosomes released biologically active molecules and posed modulatory effects on immune cells [90]. tumor released exosomes have been known for the diverse immunosuppressive effects in cancer progression [91]. One study by Wolfers et al reported exosome transfer tumor antigens from tumor cells to dendritic cells (DCs), and function in immuneinterventions [92]. In most of these studies, exosomes delivered negative signals and posed suppressive effects on anti-tumour immune responses in breast cancer, as suppress specific $\mathrm{T}$ cell immunity and convert immune cells into pro-tumorigenic phenotypes [8]. Tumor-derived exosomes expressed functional CD39 and CD73, which resulted in de-phosphorylation of exogenous ATP and 5'AMP to procedure adenosine, and rising adenosine can attenuate $\mathrm{T}$ cell function [93]. DC-secreted exosomes (DCex) induced apoptosis by activation of caspase, activated natural killer cells and killed tumor cells [94]

Myeloid-derived suppressor cells (MDSCs) facilitated immunosuppressive functions and contributed to tumor progression [95]. Exosomes isolated from cancer-secreted exosomes which contained and promoted 
tumor growth [96]. Breast tumor-derived exosomes have also been found contributed to the growth of tumors by blocking IL-2-mediated activation of NK cells and their immune response to tumor cells [97]. Humor tumorderived exosomes, as immune inhibitory, exosomal delivery of TGF $\beta 1$ to T cell or NK cell lead to downregulation of NKG2D expression [98, 99]. Circulating Exosomes secreted by breast cancer contributed to NF- $\kappa \mathrm{B}$ activation of macrophages and induced pro-inflammatory activity by upregulation of inflammatory cytokines [100].

Interestingly, studies have discovered that human breast milk contains exosomes with immune modulatory for the development of the infant's immune system [101]. Consistent with prior research conclusions, immunerelated exosomal miRNAs from breast milk are resistant to general harsh conditions, and are essential for the development of infant immune system [102].

\section{EXOSOMES ACT AS MEDIATORS OF THERAPY RESISTANCE IN BREAST CANCER}

Breast cancer therapy has received many restrictions due to therapy resistance, explanation of mechanisms responsible for drug resistance and seeking reliable indicators to predict the therapeutic effect is essential to achieve more effective and individualized chemotherapeutic treatment of breast cancer patients. Currently, some studies have shown that breast cancer exosome-mediated transfer of genetic information can induce therapy resistance and promote tumor progression, such as extruding hydrophilic drugs from cancer cells [103-105]. Studies also implied roles of exosomes in breast cancer radiotherapy resistance and cancer immunotherapy [106, 107]. (Figure 5)

\section{CHEMOTHERAPY RESISTANCE}

As breast cancer cells escape chemotherapy via various mechanisms, resistance to chemotherapy drugs remains a essential issue in the management of patients. As information transporters of intercellular communication, exosomes help cancer cells export chemotherapeutic drugs, which may facilitate the development of chemotherapy resistance. lead to chemo-resistance [5].

In breast cancer, drug-resistant breast cancer cells may spread resistance capacity and alter chemosusceptibility in recipient sensitive cells via intercellular transfer of exosomal miRNAs (including miR-100, miR222, and miR-30a) [107] [108]. The intercellular transport of P-glycoprotein (P-gp) was known to be involved in drug resistance via drug efflux across membranes [109, 110]. Exosomes mediated drug resistance via delivering P-gp from docetaxel-resistant cells to sensitive ones [111]. Jaiswal et al found that exosomes secreted by doxorubicin- resistant breast cancer cells contained abundant regulatory miRNAs (miR-451 and miR-326) and the latter conferred a more deleterious phenotype through "re-templating" recipient breast cancer cells' transcriptional landscape to reflect the P-glycoprotein over-expressed character of donor cells [112]. Exosomes from doxorubicin-resistant breast cancer cells spread resistance capacity in recipient cells by delivering miRNAs, such as miR-100, miR-222, and miR-30a [113], and exosomal miRNAs can also transmit drug resistance to sensitive cells [114]. Exosomes derived from stromal fibroblasts transferred noncoding RNA to breast cancer cells and contribute to treatment resistance through expanding therapy-resistant tumorinitiating cells. [115].

\section{IRRADIATION THERAPY}

Radiotherapy is a significant treatment method in breast cancer. Generally, oxygen is indispensable for radiation cytotoxic to cause DNA damage. Thus, breast cancer can be more resistant to radiation therapy under hypoxic microenvironment, and it has been shown that hypoxia leads to the increased production of exosomes [116] [117]. Besides, exosomes transferred from stromal to breast cancer cells stimulates antiviral signaling and derived radiation resistance in primary tumor [115]. Another study indicated that the proteome profiles of tumor-derived exosomes have been implicated in the indication of the oxygenation status of breast tumors [117].

\section{ENDOCRINE THERAPY AND TARGET THERAPY}

Tamoxifen resistance remains a daunting challenge to the successful treatment of ER-positive breast cancer. In ER-positive breast cancer, exosomes secreted from tamoxifen resistant cells (MCF-7 ${ }^{\mathrm{TamR}}$ ) significantly promoted tamoxifen sensitive cells $\left(\mathrm{MCF}-7^{\mathrm{wt}}\right)$ proliferation and colony-forming ability in the presence of tamoxifen, and this effect was partly contributed to miRNAs (miR-221/222) enclosed in exosomes. miR$221 / 222$ subsequently down-regulated its target genes of P27 and ER $\alpha$ protein levels, which caused increased tamoxifen resistance in recipient cells [118]

The clinical value of HER2-targeted therapies as trastuzumab and lapatinib is the most promising treatment for HER2 positive breast cancer patients targeted therapy. Despite this significant clinical benefit in HER2-positive patients, some patients exhibit intrinsic resistance to anti-HER2 therapy, and the underlying mechanism may be tumor cells utilizing alternative growth signaling or intracellular transduction molecules to bypass HER2 blockade $[119,120]$. Tumor exosomes carrying antigens that are targets for anti-tumor antibodies, therefore competitively inhibit the drug activity and contribute to 
treatment failure. Consistent with these results, HER2 positive derived exosomes from BT-474 and SK-BR-3 cells interfered with the bioactivity of HER2-targeted therapeutic drugs by directing binding to Trastuzumab and prevented cancer cells from the anti-proliferative effects of trastuzumab. By contrast, no negative influence on the anti-proliferative activity of Lapatinib was observed [103, $121,122]$. The schematic in Figure 5 indicates the roles of cancer exosomes in modulating sensitivity to anti-HER2 therapy. Furthermore, HER2+ exosomes can be indicative of the stages of tumor development and HER2-related tumor aggressiveness. Exosomes isolated from HER2positive advanced stage breast cancer patients' serum presented higher-level binding ability to Trastuzumab compared to exosomes purified from the serum of those in early stage [107].

\section{EXOSOMES: FUTURE CHALLENGES}

Exosomes have been proven to be important regulators in health and disease, especially in tumor biology. Tumor derived exosomes enclosing tumorspecific antigens and nucleic acids can be assessed noninvasive as potential diagnostic and predictive biomarker. Besides, exosomes could potentially be used to identify patients who are likely to develop metastatic disease, and the process of exosome production could yield new targets for cancer therapy.

\section{DIAGNOSIS AND PROGNOSIS MARKER}

Cancer derived exosome release was accumulating in tumor cells, which could be isolated from serum, pleural effusions, urine, and ascites fluids of cancer patients [123]. Alterations in expression levels of certain exosomal biomarkers from body fluids of cancer patients propose a role for exosomes as an early marker for diagnosis and prognosis monitoring. In breast cancer patients, the levels of CEA and CA153 in circulating exosomes are linked to cancer progression [24] [123].

The biomarker potential for exosomes holds huge promise for diagnose and manage breast cancer. Circulating exosome-encapsulated microRNAs presented as an early ideal biomarker for breast cancer, and expression pattern of exosomal miRNAs is also correlated with tumor malignancy degree and prognosis [15, 125].. qRT-PCR and small RNA sequencing analysis of the microRNA content from plasma exosomes of patients with revealed that miR-21 and miR-1246 were detected significantly higher levels, as compared to those of healthy control [126]. Several miRNAs have been proved to be associated with breast tumor subtype and stage. Exosomal MiR-939 was found highly expressed in the basal-like tumor subtypes and associated with worse prognosis in triple-negative breast cancers [127]. One research has revealed that decreased several levels of exosomal miR-
101 concentrations are associated with lymph-node positive cancer, and miR-373 levels were significantly upregulated in triple negative and ER and PR negative breast cancer patients [128]. By comparing tumor derived exosomes at baseline, pre-treatment and post-treatment, during follow up, and correlating with both clinical and pathologic response, we might also be able to predict therapeutic response and patient prognosis. Taken together, these reports suggested the roles of exosomes as promising biomarkers for the early diagnose of breast cancers and for evaluation of therapeutic effect and the patient's outcome.

\section{EXOSOMES-BASED THERAPY}

Exosome involvement as carriers of cellular information in cancer progression is a promising strategy in the field of vectors for targeted drug delivery. And well established functional exosomes mimetics strongly increased the pharmaceutical acceptability of such drug delivery system [129]. Via drug delivery abilities for breast cancer target therapy, exosomes delivered chemotherapeutics such as doxorubicin to tumor tissue and suppressed cancer growth [130]. As natural carriers of miRNA, exosomes could be exploited as an RNA drug delivery system as cancer therapy. One study has examined that modified exosomes can be used to transfer nucleic acid drugs such as let-7a to epidermal growth factor receptor (EGFR)-positive breast cancer cells [131]. Recently, different groups have demonstrated that exosomes can be loaded on doxorubicin and with the aid of targeting moieties can efficiently release doxorubicin to different types of cancer cells [132]. In breast and ovarian cancer mouse models, exosomal doxorubicin significantly increased the therapeutic index of doxorubicin and limited the crossing of doxorubicin through the myocardial endothelial cells and avoiding accumulation of drug in the heart without affecting other organs. [133]. However, several essential issues need to be resolved to use exosomes more efficiently and widely. For instance, the drug delivery system requires that nucleic acid drugs can be efficiently transfected into exosomes, and the suitable host cells for exosome injection is an essential factor for future clinical applications.

Exosomes have been found to be involved in modulation of immune system, and the clinical use of exosomes showed promising results in cancer immunotherapy $[134,135]$. Autologous dendritic cellderived exosomes have been proved to be well tolerated in patients with advanced non-small cell lung cancer and metastatic melanoma [136, 137]. Therapeutic filtration of cancer exosomes from the circulation could alleviate exosome-mediated immune suppression and increase cancer immunotherapy efficacy [138]. Since tumorderived exosomes contained various cytosolic and membranous tumor antigens, exosomes have been used as a nanoscale cancer vaccine and a promising candidate for 
cancer therapy [139].

\section{CONCLUSION}

Exosomes can act as critical signal transduction facilitators between cancer cells and their recipient cells, via releasing a wide variety of biological molecules, such as miRNAs, proteins and their complexes, affecting the interaction of distant cancer cells in the tumor microenvironment and the breast cancer progress. In this review, we further elaborate the contribution of the cancer and stromal cells derived exosomes to regulating breast cancer progression. With the development of novel therapeutic strategies targeting or utilizing exosomes, it will lead to more effective prevention and intervention strategies in breast cancer therapy. However, it is critical to note that crucial contents of exosomes are still not fully elucidated, and there is still a long road to fully understand the role of exosomes in breast cancer progress. Exosomebased therapies, exosomes served as predictive and prognostic biomarkers still need to be firmly validated by further preclinical and multicenter clinical validation studies.

\section{ACKNOWLEDGMENTS}

This work is supported by National Natural Science Foundation of China (No. 81602471 , No. 81672729, No. 8167284), Natural Science Foundation of Zhejiang Province (No. Q16H160010) by grant from sub-project of China National Program on Key Basic Research Project (973 Program) (No. 2014CB744505).

\section{CONFLICTS OF INTERESTS}

The authors declare that they have no competing interests.

\section{REFERENCES}

1. Bombonati A, Sgroi DC. The molecular pathology of breast cancer progression. J Pathol. 2011; 223:307-17.

2. Siegel RL, Miller KD, Jemal A. Cancer statistics, 2016. CA Cancer J Clin. 2016; 66:7-30.

3. Vader P, Breakefield XO, Wood MJ. Extracellular vesicles: emerging targets for cancer therapy. Trends Mol Med. 2014; 20:385-93.

4. Skog J, Würdinger T, van Rijn S, Meijer DH, Gainche L, Sena-Esteves M, Curry WT Jr, Carter BS, Krichevsky AM, Breakefield XO. Glioblastoma microvesicles transport RNA and proteins that promote tumour growth and provide diagnostic biomarkers. Nat Cell Biol. 2008; 10:1470-76.

5. Zhang HG, Grizzle WE. Exosomes: a novel pathway of local and distant intercellular communication that facilitates the growth and metastasis of neoplastic lesions. Am J
Pathol. 2014; 184:28-41.

6. Valadi H, Ekström K, Bossios A, Sjöstrand M, Lee JJ, Lötvall JO. Exosome-mediated transfer of mRNAs and microRNAs is a novel mechanism of genetic exchange between cells. Nat Cell Biol. 2007; 9:654-59.

7. Théry C. Exosomes: secreted vesicles and intercellular communications. F1000 Biol Rep. 2011; 3:15.

8. Iero M, Valenti R, Huber V, Filipazzi P, Parmiani G, Fais S, Rivoltini L. Tumour-released exosomes and their implications in cancer immunity. Cell Death Differ. 2008; 15:80-88.

9. Greening DW, Gopal SK, Mathias RA, Liu L, Sheng J, Zhu HJ, Simpson RJ. Emerging roles of exosomes during epithelial-mesenchymal transition and cancer progression. Semin Cell Dev Biol. 2015; 40:60-71.

10. Kahlert C, Kalluri R. Exosomes in tumor microenvironment influence cancer progression and metastasis. J Mol Med (Berl). 2013; 91:431-37.

11. Wang J, Hendrix A, Hernot S, Lemaire M, De Bruyne E, Van Valckenborgh E, Lahoutte T, De Wever O, Vanderkerken K, Menu E. Bone marrow stromal cellderived exosomes as communicators in drug resistance in multiple myeloma cells. Blood. 2014; 124:555-66.

12. Théry C, Ostrowski M, Segura E. Membrane vesicles as conveyors of immune responses. Nat Rev Immunol. 2009; 9:581-93.

13. Mathivanan S, Ji H, Simpson RJ. Exosomes: extracellular organelles important in intercellular communication. J Proteomics. 2010; 73:1907-20.

14. van Niel G, Porto-Carreiro I, Simoes S, Raposo G. Exosomes: a common pathway for a specialized function. J Biochem. 2006; 140:13-21.

15. Tetta C, Ghigo E, Silengo L, Deregibus MC, Camussi G. Extracellular vesicles as an emerging mechanism of cellto-cell communication. Endocrine. 2013; 44:11-19.

16. Simpson RJ, Lim JW, Moritz RL, Mathivanan S. Exosomes: proteomic insights and diagnostic potential. Expert Rev Proteomics. 2009; 6:267-83.

17. Lee TH, D'Asti E, Magnus N, Al-Nedawi K, Meehan B, Rak J. Microvesicles as mediators of intercellular communication in cancer - the emerging science of cellular 'debris'. Semin Immunopathol. 2011; 33:455-67.

18. van der Pol E, Böing AN, Harrison P, Sturk A, Nieuwland R. Classification, functions, and clinical relevance of extracellular vesicles. Pharmacol Rev. 2012; 64:676-705.

19. Witwer KW, Buzás EI, Bemis LT, Bora A, Lässer C, Lötvall J, Nolte-'t Hoen EN, Piper MG, Sivaraman S, Skog J, Théry C, Wauben MH, Hochberg F. Standardization of sample collection, isolation and analysis methods in extracellular vesicle research. J Extracell Vesicles. 2013; $2: 1-25$.

20. Urbanelli L, Magini A, Buratta S, Brozzi A, Sagini K, Polchi A, Tancini B, Emiliani C. Signaling pathways in exosomes biogenesis, secretion and fate. Genes (Basel). 
$2013 ; 4: 152-70$.

21. Raposo G, Stoorvogel W. Extracellular vesicles: exosomes, microvesicles, and friends. J Cell Biol. 2013; 200:373-83.

22. Heijnen HF, Schiel AE, Fijnheer R, Geuze HJ, Sixma JJ. Activated platelets release two types of membrane vesicles: microvesicles by surface shedding and exosomes derived from exocytosis of multivesicular bodies and alphagranules. Blood. 1999; 94:3791-99.

23. Graner MW, Cumming RI, Bigner DD. The heat shock response and chaperones/heat shock proteins in brain tumors: surface expression, release, and possible immune consequences. J Neurosci. 2007; 27:11214-27.

24. Dreyer F, Baur A. Biogenesis and Functions of Exosomes and Extracellular Vesicles. Methods Mol Biol. 2016;1448:201-16.

25. Riches A, Campbell E, Borger E, Powis S. Regulation of exosome release from mammary epithelial and breast cancer cells - a new regulatory pathway. Eur J Cancer. 2014; 50:1025-34.

26. Feng D, Zhao WL, Ye YY, Bai XC, Liu RQ, Chang LF, Zhou Q, Sui SF. Cellular internalization of exosomes occurs through phagocytosis. Traffic. 2010; 11:675-87.

27. Calzolari A, Raggi C, Deaglio S, Sposi NM, Stafsnes M, Fecchi K, Parolini I, Malavasi F, Peschle C, Sargiacomo M, Testa U. TfR2 localizes in lipid raft domains and is released in exosomes to activate signal transduction along the MAPK pathway. J Cell Sci. 2006; 119:4486-98.

28. Koumangoye RB, Sakwe AM, Goodwin JS, Patel T, Ochieng J. Detachment of breast tumor cells induces rapid secretion of exosomes which subsequently mediate cellular adhesion and spreading. PLoS One. 2011; 6:e24234.

29. Ogorevc E, Kralj-Iglic V, Veranic P. The role of extracellular vesicles in phenotypic cancer transformation. Radiol Oncol. 2013; 47:197-205.

30. Lee JK, Jang JY, Jeon YK, Kim CW. Extracellular Vesicles as an Emerging Paradigm of Cell-to-Cell Communication in Stem Cell Biology. J Stem Cell Res Ther. 2014; 4:206.

31. Rak J. Extracellular vesicles - biomarkers and effectors of the cellular interactome in cancer. Front Pharmacol. 2013; $4: 21$.

32. Corrado C, Raimondo S, Chiesi A, Ciccia F, De Leo G, Alessandro R. Exosomes as intercellular signaling organelles involved in health and disease: basic science and clinical applications. Int J Mol Sci. 2013; 14:5338-66.

33. Yu JL, May L, Lhotak V, Shahrzad S, Shirasawa S, Weitz J, Coomber BL, Mackman N, Rak JW. Oncogenic events regulate tissue factor expression in colorectal cancer cells: implications for tumor progression and angiogenesis. Blood. 2005; 105:1734-41.

34. Antonyak MA, Li B, Boroughs LK, Johnson JL, Druso JE, Bryant KL, Holowka DA, Cerione RA. Cancer cell-derived microvesicles induce transformation by transferring tissue transglutaminase and fibronectin to recipient cells. Proc Natl Acad Sci USA. 2011; 108:4852-57. Erratum in: Proc
Natl Acad Sci U S A. 2011;108:17569.

35. Melo SA, Sugimoto H, O'Connell JT, Kato N, Villanueva A, Vidal A, Qiu L, Vitkin E, Perelman LT, Melo CA, Lucci A, Ivan C, Calin GA, Kalluri R. Cancer exosomes perform cell-independent microRNA biogenesis and promote tumorigenesis. Cancer Cell. 2014; 26:707-21.

36. Sethi N, Kang Y. Unravelling the complexity of metastasis - molecular understanding and targeted therapies. Nat Rev Cancer. 2011; 11:735-48.

37. Frost AR, Hurst DR, Shevde LA, Samant RS. The influence of the cancer microenvironment on the process of metastasis. Int J Breast Cancer. 2012; 2012:756257.

38. Brábek J, Mierke CT, Rösel D, Veselý P, Fabry B. The role of the tissue microenvironment in the regulation of cancer cell motility and invasion. Cell Commun Signal. 2010; 8:22.

39. Ochieng J, Pratap S, Khatua AK, Sakwe AM. Anchorageindependent growth of breast carcinoma cells is mediated by serum exosomes. Exp Cell Res. 2009; 315:1875-88.

40. Nie Z. Fetuin: its enigmatic property of growth promotion. Am J Physiol. 1992; 263:C551-62.

41. Watson K, Koumangoye R, Thompson P, Sakwe AM, Patel T, Pratap S, Ochieng J. Fetuin-A triggers the secretion of a novel set of exosomes in detached tumor cells that mediate their adhesion and spreading. FEBS Lett. 2012; 586:345863.

42. Jung T, Castellana D, Klingbeil P, Cuesta Hernández I, Vitacolonna M, Orlicky DJ, Roffler SR, Brodt P, Zöller M. CD44v6 dependence of premetastatic niche preparation by exosomes. Neoplasia. 2009; 11:1093-105.

43. Nangami G, Koumangoye R, Shawn Goodwin J, Sakwe AM, Marshall D, Higginbotham J, Ochieng J. Fetuin-A associates with histones intracellularly and shuttles them to exosomes to promote focal adhesion assembly resulting in rapid adhesion and spreading in breast carcinoma cells. Exp Cell Res. 2014; 328:388-400.

44. Harris DA, Patel SH, Gucek M, Hendrix A, Westbroek W, Taraska JW. Exosomes released from breast cancer carcinomas stimulate cell movement. PLoS One. 2015; 10:e0117495.

45. Kruger S, Abd Elmageed ZY, Hawke DH, Wörner PM, Jansen DA, Abdel-Mageed AB, Alt EU, Izadpanah R. Molecular characterization of exosome-like vesicles from breast cancer cells. BMC Cancer. 2014; 14:44.

46. Singh R, Pochampally R, Watabe K, Lu Z, Mo YY. Exosome-mediated transfer of miR-10b promotes cell invasion in breast cancer. Mol Cancer. 2014; 13:256.

47. Zhou W, Fong MY, Min Y, Somlo G, Liu L, Palomares MR, Yu Y, Chow A, O'Connor ST, Chin AR, Yen Y, Wang $\mathrm{Y}$, Marcusson EG, et al. Cancer-secreted miR-105 destroys vascular endothelial barriers to promote metastasis. Cancer Cell. 2014; 25:501-15.

48. Fong MY, Zhou W, Liu L, Alontaga AY, Chandra M, Ashby J, Chow A, O'Connor ST, Li S, Chin AR, Somlo G, Palomares M, Li Z, et al. Breast-cancer-secreted miR-122 
reprograms glucose metabolism in premetastatic niche to promote metastasis. Nat Cell Biol. 2015; 17:183-94.

49. Baroni S, Romero-Cordoba S, Plantamura I, Dugo M, D'Ippolito E, Cataldo A, Cosentino G, Angeloni V, Rossini A, Daidone MG, Iorio MV. Exosome-mediated delivery of miR-9 induces cancer-associated fibroblast-like properties in human breast fibroblasts. Cell Death Dis. 2016; 7:e2312.

50. Lim PK, Bliss SA, Patel SA, Taborga M, Dave MA, Gregory LA, Greco SJ, Bryan M, Patel PS, Rameshwar P. Gap junction-mediated import of microRNA from bone marrow stromal cells can elicit cell cycle quiescence in breast cancer cells. Cancer Res. 2011; 71:1550-60.

51. Ono M, Kosaka N, Tominaga N, Yoshioka Y, Takeshita F, Takahashi RU, Yoshida M, Tsuda H, Tamura K, Ochiya T. Exosomes from bone marrow mesenchymal stem cells contain a microRNA that promotes dormancy in metastatic breast cancer cells. Sci Signal. 2014; 7:ra63.

52. O'Brien K, Rani S, Corcoran C, Wallace R, Hughes L, Friel AM, McDonnell S, Crown J, Radomski MW, O’Driscoll L. Exosomes from triple-negative breast cancer cells can transfer phenotypic traits representing their cells of origin to secondary cells. Eur J Cancer. 2013; 49:1845-1859.

53. Eichelser C, Stückrath I, Müller V, Milde-Langosch K, Wikman H, Pantel K, Schwarzenbach H. Increased serum levels of circulating exosomal microRNA-373 in receptornegative breast cancer patients. Oncotarget. 2014; 5:9650 63. doi: 10.18632/oncotarget.2520.

54. Luga V, Zhang L, Viloria-Petit AM, Ogunjimi AA, Inanlou MR, Chiu E, Buchanan M, Hosein AN, Basik M, Wrana JL. Exosomes mediate stromal mobilization of autocrine WntPCP signaling in breast cancer cell migration. Cell. 2012; 151:1542-56.

55. Yang M, Chen J, Su F, Yu B, Su F, Lin L, Liu Y, Huang JD, Song E. Microvesicles secreted by macrophages shuttle invasion-potentiating microRNAs into breast cancer cells. Mol Cancer. 2011; 10:117.

56. Dhani N, Fyles A, Hedley D, Milosevic M. The clinical significance of hypoxia in human cancers. Semin Nucl Med. 2015; 45:110-21.

57. Wang T, Gilkes DM, Takano N, Xiang L, Luo W, Bishop CJ, Chaturvedi P, Green JJ, Semenza GL. Hypoxiainducible factors and RAB22A mediate formation of microvesicles that stimulate breast cancer invasion and metastasis. Proc Natl Acad Sci USA. 2014; 111:E3234-42.

58. King HW, Michael MZ, Gleadle JM. Hypoxic enhancement of exosome release by breast cancer cells. BMC Cancer. 2012; 12:421.

59. Svensson KJ, Kucharzewska P, Christianson HC, Sköld S, Löfstedt T, Johansson MC, Mörgelin M, Bengzon J, Ruf W, Belting M. Hypoxia triggers a proangiogenic pathway involving cancer cell microvesicles and PAR-2-mediated heparin-binding EGF signaling in endothelial cells. Proc Natl Acad Sci USA. 2011; 108:13147-52.

60. Orriss IR, Knight GE, Utting JC, Taylor SE, Burnstock G,
Arnett TR. Hypoxia stimulates vesicular ATP release from rat osteoblasts. J Cell Physiol. 2009; 220:155-62.

61. Wysoczynski M, Ratajczak MZ. Lung cancer secreted microvesicles: underappreciated modulators of microenvironment in expanding tumors. Int J Cancer. 2009; 125:1595-603.

62. Kucharzewska P, Christianson HC, Welch JE, Svensson KJ, Fredlund E, Ringnér M, Mörgelin M, Bourseau-Guilmain E, Bengzon J, Belting M. Exosomes reflect the hypoxic status of glioma cells and mediate hypoxia-dependent activation of vascular cells during tumor development. Proc Natl Acad Sci USA. 2013; 110:7312-17.

63. Taylor DD, Gerçel-Taylor C. Tumour-derived exosomes and their role in cancer-associated T-cell signalling defects. Br J Cancer. 2005; 92:305-11.

64. Zhang HC, Liu XB, Huang S, Bi XY, Wang HX, Xie LX, Wang YQ, Cao XF, Lv J, Xiao FJ, Yang Y, Guo ZK. Microvesicles derived from human umbilical cord mesenchymal stem cells stimulated by hypoxia promote angiogenesis both in vitro and in vivo. Stem Cells Dev. 2012; 21:3289-97.

65. Parolini I, Federici C, Raggi C, Lugini L, Palleschi S, De Milito A, Coscia C, Iessi E, Logozzi M, Molinari A, Colone M, Tatti M, Sargiacomo M, Fais S. Microenvironmental pH is a key factor for exosome traffic in tumor cells. J Biol Chem. 2009; 284:34211-22.

66. Park JE, Tan HS, Datta A, Lai RC, Zhang H, Meng W, Lim SK, Sze SK. Hypoxic tumor cell modulates its microenvironment to enhance angiogenic and metastatic potential by secretion of proteins and exosomes. Mol Cell Proteomics. 2010; 9:1085-99.

67. Salomon C, Ryan J, Sobrevia L, Kobayashi M, Ashman K, Mitchell M, Rice GE. Exosomal signaling during hypoxia mediates microvascular endothelial cell migration and vasculogenesis. PLoS One. 2013; 8:e68451.

68. Papi A, De Carolis S, Bertoni S, Storci G, Sceberras V, Santini D, Ceccarelli C, Taffurelli M, Orlandi M, Bonafé M. PPAR $\gamma$ and RXR ligands disrupt the inflammatory crosstalk in the hypoxic breast cancer stem cells niche. J Cell Physiol. 2014; 229:1595-606.

69. Vaupel P, Briest S, Höckel M. Hypoxia in breast cancer: pathogenesis, characterization and biological/therapeutic implications. Wien Med Wochenschr. 2002; 152:334-42.

70. Spaeth E, Klopp A, Dembinski J, Andreeff M, Marini F. Inflammation and tumor microenvironments: defining the migratory itinerary of mesenchymal stem cells. Gene Ther. 2008; 15:730-38.

71. Chamberlain G, Fox J, Ashton B, Middleton J. Concise review: mesenchymal stem cells: their phenotype, differentiation capacity, immunological features, and potential for homing. Stem Cells. 2007; 25:2739-49.

72. Karnoub AE, Dash AB, Vo AP, Sullivan A, Brooks MW, Bell GW, Richardson AL, Polyak K, Tubo R, Weinberg RA. Mesenchymal stem cells within tumour stroma promote 
breast cancer metastasis. Nature. 2007; 449:557-63.

73. Cho JA, Park H, Lim EH, Lee KW. Exosomes from breast cancer cells can convert adipose tissue-derived mesenchymal stem cells into myofibroblast-like cells. Int J Oncol. 2012; 40:130-38.

74. Lin R, Wang S, Zhao RC. Exosomes from human adiposederived mesenchymal stem cells promote migration through Wnt signaling pathway in a breast cancer cell model. Mol Cell Biochem. 2013; 383:13-20.

75. Shi J, Ren Y, Zhen L, Qiu X. Exosomes from breast cancer cells stimulate proliferation and inhibit apoptosis of CD133+ cancer cells in vitro. Mol Med Rep. 2015; 11:40509.

76. Cho JA, Park H, Lim EH, Kim KH, Choi JS, Lee JH, Shin JW, Lee KW. Exosomes from ovarian cancer cells induce adipose tissue-derived mesenchymal stem cells to acquire the physical and functional characteristics of tumorsupporting myofibroblasts. Gynecol Oncol. 2011; 123:37986.

77. Lee JK, Park SR, Jung BK, Jeon YK, Lee YS, Kim MK, Kim YG, Jang JY, Kim CW. Exosomes derived from mesenchymal stem cells suppress angiogenesis by downregulating VEGF expression in breast cancer cells. PLoS One. 2013; 8:e84256.

78. Kosaka N, Iguchi H, Hagiwara K, Yoshioka Y, Takeshita F, Ochiya T. Neutral sphingomyelinase 2 (nSMase2)dependent exosomal transfer of angiogenic microRNAs regulate cancer cell metastasis. J Biol Chem. 2013; 288:10849-59.

79. Camacho L, Guerrero P, Marchetti D. MicroRNA and protein profiling of brain metastasis competent cell-derived exosomes. PLoS One. 2013; 8:e73790.

80. Hong L, Yang J, Han Y, Lu Q, Cao J, Syed L. High expression of miR-210 predicts poor survival in patients with breast cancer: a meta-analysis. Gene. 2012; 507:13538.

81. Kaplan RN, Rafii S, Lyden D. Preparing the "soil": the premetastatic niche. Cancer Res. 2006; 66:11089-93.

82. Vlassov AV, Magdaleno S, Setterquist R, Conrad R. Exosomes: current knowledge of their composition, biological functions, and diagnostic and therapeutic potentials. Biochim Biophys Acta. 2012; 1820:940-8.

83. Dutta S, Warshall C, Bandyopadhyay C, Dutta D, Chandran B. Interactions between exosomes from breast cancer cells and primary mammary epithelial cells leads to generation of reactive oxygen species which induce DNA damage response, stabilization of p53 and autophagy in epithelial cells. PLoS One. 2014; 9:e97580.

84. Suetsugu A, Honma K, Saji S, Moriwaki H, Ochiya T, Hoffman RM. Imaging exosome transfer from breast cancer cells to stroma at metastatic sites in orthotopic nude-mouse models. Adv Drug Deliv Rev. 2013; 65:383-90.

85. Peinado H, Lavotshkin S, Lyden D. The secreted factors responsible for pre-metastatic niche formation: old sayings and new thoughts. Semin Cancer Biol. 2011; 21:139-46.

86. Gernapudi R, Yao Y, Zhang Y, Wolfson B, Roy S, Duru N, Eades G, Yang P, Zhou Q. Targeting exosomes from preadipocytes inhibits preadipocyte to cancer stem cell signaling in early-stage breast cancer. Breast Cancer Res Treat. 2015; 150:685-95.

87. Hoshino A, Costa-Silva B, Shen TL, Rodrigues G, Hashimoto A, Tesic Mark M, Molina H, Kohsaka S, Di Giannatale A, Ceder S, Singh S, Williams C, Soplop N, et al. Tumour exosome integrins determine organotropic metastasis. Nature. 2015; 527:329-35.

88. Liu Y, Cao X. Organotropic metastasis: role of tumor exosomes. Cell Res. 2016; 26:149-50.

89. Blankenstein T, Coulie PG, Gilboa E, Jaffee EM. The determinants of tumour immunogenicity. Nat Rev Cancer. 2012; 12:307-13.

90. Robbins PD, Morelli AE. Regulation of immune responses by extracellular vesicles. Nat Rev Immunol. 2014; 14:195208.

91. Filipazzi P, Bürdek M, Villa A, Rivoltini L, Huber V. Recent advances on the role of tumor exosomes in immunosuppression and disease progression. Semin Cancer Biol. 2012; 22:342-49.

92. Wolfers J, Lozier A, Raposo G, Regnault A, Théry C, Masurier C, Flament C, Pouzieux S, Faure F, Tursz T, Angevin E, Amigorena S, Zitvogel L. Tumor-derived exosomes are a source of shared tumor rejection antigens for CTL cross-priming. Nat Med. 2001; 7:297-303.

93. Clayton A, Al-Taei S, Webber J, Mason MD, Tabi Z. Cancer exosomes express CD39 and CD73, which suppress $\mathrm{T}$ cells through adenosine production. J Immunol. 2011; 187:676-83.

94. Munich S, Sobo-Vujanovic A, Buchser WJ, Beer-Stolz D, Vujanovic NL. Dendritic cell exosomes directly kill tumor cells and activate natural killer cells via TNF superfamily ligands. OncoImmunology. 2012; 1:1074-83.

95. Hong EH, Chang SY, Lee BR, Kim YS, Lee JM, Kang CY, Kweon MN, Ko HJ. Blockade of Myd88 signaling induces antitumor effects by skewing the immunosuppressive function of myeloid-derived suppressor cells. Int J Cancer. $2013 ; 132: 2839-48$.

96. Xiang X, Poliakov A, Liu C, Liu Y, Deng ZB, Wang J, Cheng Z, Shah SV, Wang GJ, Zhang L, Grizzle WE, Mobley J, Zhang HG. Induction of myeloid-derived suppressor cells by tumor exosomes. Int J Cancer. 2009; 124:2621-33.

97. Liu C, Yu S, Zinn K, Wang J, Zhang L, Jia Y, Kappes JC, Barnes S, Kimberly RP, Grizzle WE, Zhang HG. Murine mammary carcinoma exosomes promote tumor growth by suppression of NK cell function. J Immunol. 2006; 176:1375-85.

98. Clayton A, Tabi Z. Exosomes and the MICA-NKG2D system in cancer. Blood Cells Mol Dis. 2005; 34:206-13.

99. Clayton A, Mitchell JP, Court J, Linnane S, Mason MD, 
Tabi Z. Human tumor-derived exosomes down-modulate NKG2D expression. J Immunol. 2008; 180:7249-58.

100. Chow A, Zhou W, Liu L, Fong MY, Champer J, Van Haute D, Chin AR, Ren X, Gugiu BG, Meng Z, Huang W, Ngo V, Kortylewski M, Wang SE. Macrophage immunomodulation by breast cancer-derived exosomes requires Toll-like receptor 2-mediated activation of NF-кB. Sci Rep. 2014; 4:5750.

101. Admyre C, Johansson SM, Qazi KR, Filén JJ, Lahesmaa R, Norman M, Neve EP, Scheynius A, Gabrielsson S. Exosomes with immune modulatory features are present in human breast milk. J Immunol. 2007; 179:1969-78.

102. Zhou Q, Li M, Wang X, Li Q, Wang T, Zhu Q, Zhou X, Wang X, Gao X, Li X. Immune-related microRNAs are abundant in breast milk exosomes. Int J Biol Sci. 2012; $8: 118-23$.

103. Ciravolo V, Huber V, Ghedini GC, Venturelli E, Bianchi F, Campiglio M, Morelli D, Villa A, Della Mina P, Menard S, Filipazzi P, Rivoltini L, Tagliabue E, Pupa SM. Potential role of HER2-overexpressing exosomes in countering trastuzumab-based therapy. J Cell Physiol. 2012; 227:65867.

104. Shedden K, Xie XT, Chandaroy P, Chang YT, Rosania GR. Expulsion of small molecules in vesicles shed by cancer cells: association with gene expression and chemosensitivity profiles. Cancer Res. 2003; 63:4331-37.

105. Safaei R, Larson BJ, Cheng TC, Gibson MA, Otani S, Naerdemann W, Howell SB. Abnormal lysosomal trafficking and enhanced exosomal export of cisplatin in drug-resistant human ovarian carcinoma cells. Mol Cancer Ther. 2005; 4:1595-604.

106. Hayes JD, Wolf CR. Molecular mechanisms of drug resistance. Biochem J. 1990; 272:281-95.

107. Chen WX, Liu XM, Lv MM, Chen L, Zhao JH, Zhong SL, Ji MH, Hu Q, Luo Z, Wu JZ, Tang JH. Exosomes from drug-resistant breast cancer cells transmit chemoresistance by a horizontal transfer of microRNAs. PLoS One. 2014; 9:e95240.

108. Ma X, Chen Z, Hua D, He D, Wang L, Zhang P, Wang J, Cai Y, Gao C, Zhang X, Zhang F, Wang T, Hong T, et al. Essential role for TrpC5-containing extracellular vesicles in breast cancer with chemotherapeutic resistance. Proc Natl Acad Sci USA. 2014; 111:6389-94.

109. Dong Y, Pan Q, Jiang L, Chen Z, Zhang F, Liu Y, Xing H, Shi M, Li J, Li X, Zhu Y, Chen Y, Bruce IC, et al. Tumor endothelial expression of P-glycoprotein upon microvesicular transfer of TrpC5 derived from adriamycinresistant breast cancer cells. Biochem Biophys Res Commun. 2014; 446:85-90.

110. Yamagishi T, Sahni S, Sharp DM, Arvind A, Jansson PJ, Richardson DR. P-glycoprotein mediates drug resistance via a novel mechanism involving lysosomal sequestration. J Biol Chem. 2013; 288:31761-71.

111. Lv MM, Zhu XY, Chen WX, Zhong SL, Hu Q, Ma TF,
Zhang J, Chen L, Tang JH, Zhao JH. Exosomes mediate drug resistance transfer in MCF-7 breast cancer cells and a probable mechanism is delivery of $\mathrm{P}$-glycoprotein. Tumour Biol. 2014; 35:10773-79.

112. Jaiswal R, Gong J, Sambasivam S, Combes V, Mathys JM, Davey R, Grau GE, Bebawy M. Microparticle-associated nucleic acids mediate trait dominance in cancer. FASEB J. 2012; 26:420-29.

113. Chen WX, Cai YQ, Lv MM, Chen L, Zhong SL, Ma TF, Zhao JH, Tang JH. Exosomes from docetaxel-resistant breast cancer cells alter chemosensitivity by delivering microRNAs. Tumour Biol. 2014; 35:9649-59.

114. Mao L, Li J, Chen WX, Cai YQ, Yu DD, Zhong SL, Zhao JH, Zhou JW, Tang JH. Exosomes decrease sensitivity of breast cancer cells to adriamycin by delivering microRNAs. Tumour Biol. 2016; 37:5247-56.

115. Boelens MC, Wu TJ, Nabet BY, Xu B, Qiu Y, Yoon T, Azzam DJ, Twyman-Saint Victor C, Wiemann BZ, Ishwaran H, Ter Brugge PJ, Jonkers J, Slingerland J, Minn AJ. Exosome transfer from stromal to breast cancer cells regulates therapy resistance pathways. Cell. 2014; 159:499513.

116. Eldh M, Ekström K, Valadi H, Sjöstrand M, Olsson B, Jernås M, Lötvall J. Exosomes communicate protective messages during oxidative stress; possible role of exosomal shuttle RNA. PLoS One. 2010; 5:e15353.

117. Thomas SN, Liao Z, Clark D, Chen Y, Samadani R, Mao L, Ann DK, Baulch JE, Shapiro P, Yang AJ. Exosomal Proteome Profiling: A Potential Multi-Marker Cellular Phenotyping Tool to Characterize Hypoxia-Induced Radiation Resistance in Breast Cancer. Proteomes. 2013; 1:87-108.

118. Wei Y, Lai X, Yu S, Chen S, Ma Y, Zhang Y, Li H, Zhu X, Yao L, Zhang J. Exosomal miR-221/222 enhances tamoxifen resistance in recipient ER-positive breast cancer cells. Breast Cancer Res Treat. 2014; 147:423-31.

119. Slamon DJ, Leyland-Jones B, Shak S, Fuchs H, Paton V, Bajamonde A, Fleming T, Eiermann W, Wolter J, Pegram M, Baselga J, Norton L. Use of chemotherapy plus a monoclonal antibody against HER2 for metastatic breast cancer that overexpresses HER2. N Engl J Med. 2001; 344:783-92.

120. Tagliabue E, Balsari A, Campiglio M, Pupa SM. HER2 as a target for breast cancer therapy. Expert Opin Biol Ther. 2010; 10:711-24.

121. Battke C, Ruiss R, Welsch U, Wimberger P, Lang S, Jochum S, Zeidler R. Tumour exosomes inhibit binding of tumour-reactive antibodies to tumour cells and reduce ADCC. Cancer Immunol Immunother. 2011; 60:639-48.

122. Shah SH, Miller P, Garcia-Contreras M, Ao Z, Machlin L, Issa E, El-Ashry D. Hierarchical paracrine interaction of breast cancer associated fibroblasts with cancer cells via hMAPK-microRNAs to drive ER-negative breast cancer phenotype. Cancer Biol Ther. 2015; 16:1671-81. 
123. Andre F, Schartz NE, Movassagh M, Flament C, Pautier P, Morice P, Pomel C, Lhomme C, Escudier B, Le Chevalier T, Tursz T, Amigorena S, Raposo G, et al. Malignant effusions and immunogenic tumour-derived exosomes. Lancet. 2002; 360:295-305.

124. Toth B, Nieuwland R, Liebhardt S, Ditsch N, Steinig K, Stieber P, Rank A, Göhring P, Thaler CJ, Friese $\mathrm{K}$, Bauerfeind I. Circulating microparticles in breast cancer patients: a comparative analysis with established biomarkers. Anticancer Res. 2008; 28:1107-12.

125. Joyce DP, Kerin MJ, Dwyer RM. Exosome-encapsulated microRNAs as circulating biomarkers for breast cancer. Int J Cancer. 2016; 139:1443-48.

126. Hannafon BN, Trigoso YD, Calloway CL, Zhao YD, Lum DH, Welm AL, Zhao ZJ, Blick KE, Dooley WC, Ding WQ. Plasma exosome microRNAs are indicative of breast cancer. Breast Cancer Res. 2016; 18:90.

127. Di Modica M, Regondi V, Sandri M, Iorio MV, Zanetti A, Tagliabue E, Casalini P, Triulzi T. Breast cancer-secreted miR-939 downregulates VE-cadherin and destroys the barrier function of endothelial monolayers. Cancer Lett. 2017; 384:94-100.

128. Takahashi RU, Miyazaki H, Ochiya T. The Roles of MicroRNAs in Breast Cancer. Cancers (Basel). 2015; 7:598-616.

129. Kooijmans SA, Vader P, van Dommelen SM, van Solinge WW, Schiffelers RM. Exosome mimetics: a novel class of drug delivery systems. Int J Nanomedicine. 2012; 7:152541.

130. Tian Y, Li S, Song J, Ji T, Zhu M, Anderson GJ, Wei J, Nie G. A doxorubicin delivery platform using engineered natural membrane vesicle exosomes for targeted tumor therapy. Biomaterials. 2014; 35:2383-90.

131. Ohno S, Takanashi M, Sudo K, Ueda S, Ishikawa A, Matsuyama N, Fujita K, Mizutani T, Ohgi T, Ochiya T, Gotoh N, Kuroda M. Systemically injected exosomes targeted to EGFR deliver antitumor microRNA to breast cancer cells. Mol Ther. 2013; 21:185-91.
132. Jang SC, Kim OY, Yoon CM, Choi DS, Roh TY, Park J, Nilsson J, Lötvall J, Kim YK, Gho YS. Bioinspired exosome-mimetic nanovesicles for targeted delivery of chemotherapeutics to malignant tumors. ACS Nano. 2013; 7:7698-710.

133. Hadla M, Palazzolo S, Corona G, Caligiuri I, Canzonieri V, Toffoli G, Rizzolio F. Exosomes increase the therapeutic index of doxorubicin in breast and ovarian cancer mouse models. Nanomedicine (Lond). 2016; 11:2431-41.

134. Aline F, Bout D, Amigorena S, Roingeard P, DimierPoisson I. Toxoplasma gondii antigen-pulsed-dendritic cell-derived exosomes induce a protective immune response against T. gondii infection. Infect Immun. 2004; 72:412737.

135. Pêche H, Heslan M, Usal C, Amigorena S, Cuturi MC. Presentation of donor major histocompatibility complex antigens by bone marrow dendritic cell-derived exosomes modulates allograft rejection. Transplantation. 2003; 76:1503-10.

136. Escudier B, Dorval T, Chaput N, André F, Caby MP, Novault S, Flament C, Leboulaire C, Borg C, Amigorena S, Boccaccio C, Bonnerot C, Dhellin O, et al. Vaccination of metastatic melanoma patients with autologous dendritic cell (DC) derived-exosomes: results of thefirst phase I clinical trial. J Transl Med. 2005; 3:10.

137. Morse MA, Garst J, Osada T, Khan S, Hobeika A, Clay TM, Valente N, Shreeniwas R, Sutton MA, Delcayre A, Hsu DH, Le Pecq JB, Lyerly HK. A phase I study of dexosome immunotherapy in patients with advanced nonsmall cell lung cancer. J Transl Med. 2005; 3:9.

138. Marleau AM, Chen CS, Joyce JA, Tullis RH. Exosome removal as a therapeutic adjuvant in cancer. J Transl Med. 2012; 10:134.

139. Tan A, De La Peña H, Seifalian AM. The application of exosomes as a nanoscale cancer vaccine. Int $\mathrm{J}$ Nanomedicine. 2010; 5:889-900. 